\title{
Research Ethics Grasp and Enactment; A Case with University of Benin
} Ibeakuzie Precious Onyedikachi ${ }^{1 *}$, Guobadia Emwinloghosa Kenneth ${ }^{2,3}$

${ }^{1}$ Department of Statistics, Nnamdi Azikiwe University, Awka, Nigeria

${ }^{2}$ Department of Administration, Federal Medical Centre, Asaba, Delta State, Nigeria

${ }^{3}$ Department of Statistics, University of Benin, Benin, Nigeria

DOI: $10.36348 /$ sb.2021.v07i03.007 $\quad$ | Received: 27.02.2021 | Accepted: 18.03.2021 | Published: 22.03.2021

*Corresponding author: Ibeakuzie Precious Onyedikachi

\section{Abstract}

Bioethics involves the objective assessment of how others, including animals and the environment, are affected by our values, desires, and actions. Bioethics covers global ethics, a field that focuses on the connection between biology, ecology, medicine, and human values. In this study, the understanding of research ethics information among students at the University of Benin was determined; we accessed the research ethics training knowledge base to understand constraints on the proper use of bioethics and research ethics. We also have access to the knowledge transfer rate of research ethics training conducted at the University of Benin; and the level of understanding of ethics compared between different fields of study. Findings from the study indicated that the respondents performed better $(\bar{x}=16.77, \mathrm{SD}=3.36)$ after they were exposed to ethics training, Results showed that there is a statistically significant and positive relationship between students' academic qualification and ethics knowledge/practice $(r=0.26 ; p<0.05)$, Similarly, there is a statistically significant and direct relationship between students' research experience and their ethics knowledge $(\mathrm{r}=$ $0.19 ; \mathrm{p}<0.05)$. However, the model does not reliably predict research ethics knowledge and practice $[\mathrm{F}(6,103)=1.919$, $\mathrm{p}>0.05]$

Keywords: Research ethics, Uniben, scientific research, bioethics, regression, ANCOVA.

Copyright (C) 2021 The Author(s): This is an open-access article distributed under the terms of the Creative Commons Attribution 4.0 International License (CC BY-NC 4.0) which permits unrestricted use, distribution, and reproduction in any medium for non-commercial use provided the original author and source are credited.

\section{INTRODUCTION}

The codes of conduct for scientific researchers are regulated by research ethics. In order to protect the dignity, rights and health of research subjects, it is necessary to adhere to ethical standards. As such, an ethics committee should review all research involving human beings to ensure that the required ethical principles are upheld. For ethical analysis, discussion of the ethical standards of beneficence, fairness and autonomy are central [1-3]. The WHO Handbook (Section XV.2) describes human subject study as 'any social science, biomedical, behavioral, or epidemiological operation that includes systematic data collection or analysis in order to produce new information in which human beings are subjected to direct or altered coercion, interference, observation, or other contact with investigators [4-6]. Bioethics includes the critical evaluation of how others, including animals and the environment, are influenced by our beliefs, wishes, and behavior. Bioethics encompasses global ethics, an area that focuses on the relationship between nature, ecology, medicine, and human values.
Medical bioethics is focused on topics affecting human health and well-being, such as euthanasia, adoptive parenting, and genetic engineering [7-10]. In 1926, Fritz Jahr referred to the word "bioethics" (Greek bios, life; ethos, behavior) in an article on a "bioethical imperative" surrounding the use of animals and plants in scientific research. The work of Renssealer Potter played a coherent role in the creation of today's bioethics, or the fact that many writers who predated Potter had already acknowledged that there were incomplete "bridges" linking natural sciences with humanities and social sciences. Even in the less exclusive version that indicates the "bi-location" of the emergence of this word, although the syner-gic influence of Potter's work on the formation of the field of bioethics must be recognized [11-14]. In this report, efforts will be made: to assess and access understanding of research ethics information among students at the University of Benin; to access the research ethics training knowledge base; to recognize constraints on the proper use of bioethics and research ethics; to access 
the knowledge transfer rate of research ethics training to be undertaken at the University of Benin.

\section{METHODOLOGY}

Research Design

A non-experimental research survey will be implemented for the study. Data on current phenomena will be obtained from participants without any randomization or manipulation.

\section{Study Population}

The research population comprises all fulltime postgraduate students from Benin University, Benin. This involves both male and female postgraduates who are studying at university at the moment.

\section{Sample and Sampling Technique}

The studies will be chosen deliberately by the Faculties of Science, Arts and Medicine. In order to participate in the research, postgraduates in these schools will be randomly chosen. It will be carried out by skilled and qualified researchers and research assistants in order to gather detailed data and take precise measurements. The only way to sample remains when the intended population includes an infinite number of participants. Sampling can also seem to be the only way to obtain data under certain situations, since it provides a reliable sampling error estimate.

\section{Data Collection Procedure}

For this analysis, primary data and secondary data will be used. In addition to the administration of questionnaires on respondents, existing records from appropriate source documents will be curated for this analysis so as to provide robust data for the study.

\section{Methods of Data Analysis}

For analysis, data from the field will be obtained, cleaned and entered into statistical software (STATA and SPSS). Ratio checks will be performed. Variance analysis (ANOVA) and regression analysis will also be performed to evaluate the equality of groups' means and to evaluate the significant predictors of ethical awareness practice among respondents, respectively [15-17]. Using means and proportions, descriptive analysis will be performed. Using Fisher's exact test, variations in means will be checked and chisquared tests will be used to identify differences in proportions. From the primary and secondary data obtained, composite compression scores will be produced and the findings will be dichotomized. Study of univariate logistic regression will be conducted to classify relevant predictors at significance level 0.05. These variables will be used in multivariate logistic regression models and used to classify predictors of the community, knowledge and practice of ethics among research participants, i.e. postgraduate students of the University of Benin, Benin, Nigeria, according to this model of prediction of the chances of experiencing an occurrence.

$$
\frac{p}{1-p}=\frac{e^{\alpha+\beta_{1} x_{1}} /\left(1+e^{\alpha+\beta_{1} x_{1}}\right)}{\left[1 /\left(1+e^{\alpha+\beta_{1} x_{1}}\right)\right]}=e^{\alpha+\beta_{1} x_{1}}
$$

And taking the natural logarithm of each side of the equation

$$
\ln \left[\frac{p}{1-p}\right]=\alpha+\beta_{1} x_{1}
$$

\section{Multiple Linear Regressions}

So far, we have seen the notion of simple linear regression where the response variable $\mathrm{Y}$ was modelled using a single predictor variable $\mathrm{X}$. There is more than one factor in many applications which influences the response. Therefore, some regression models explain how a single response variable $\mathrm{Y}$ depends on a number of predictor variables linearly.

\section{Estimation of the Model Parameters}

Although the parameters of more complex linear models can be calculated, the computations are quite quickly becoming quite complicated. Thus, to make the calculations more accurate, we will use linear algebra methods.

The setup: Consider a multiple linear regression model with $k$ independent predictor variables $x_{1}, \ldots, x_{k}$ and one response variable $y$.

$$
y=\beta_{0}+\beta_{1} x_{1}+\cdots+\beta_{k} x_{k}+\varepsilon
$$

Suppose, we have $n$ observations on the $k+1$ variables.

$$
y=\beta_{0}+\beta_{1} x_{i 1}+\cdots+\beta_{k} x_{i k}+\varepsilon_{i}, \quad i=1, \ldots, n
$$

We could take derivatives with respect to the model parameters $\beta_{0}, \ldots, \beta_{k}$, set them equal to zero and derive the least-squares normal equations that our parameter estimates $\beta^{\wedge}, \ldots, \beta^{\wedge}{ }_{k}$ would have to fulfill.

$$
\begin{gathered}
n \hat{\beta}_{0}+\hat{\beta}_{1} \sum_{i=1}^{n} x_{i 1}+\hat{\beta}_{2} \sum_{i=1}^{n} x_{i 2}+\cdots+\hat{\beta}_{k} \sum_{i=1}^{n} x_{i k}=\sum_{i=1}^{n} y_{i} \\
\hat{\beta}_{0} \sum_{i=1}^{n} x_{i 1}+\hat{\beta}_{1} \sum_{i=1}^{n} x^{2}{ }_{i 1}+\hat{\beta}_{2} \sum_{i=1}^{n} x_{i 1} x_{i 2}+\cdots+\hat{\beta}_{k} \sum_{i=1}^{n} x_{i 1} x_{i k}=\sum_{i=1}^{n} x_{i 1} y_{i}
\end{gathered}
$$




$$
\hat{\beta}_{0} \sum_{i=1}^{n} x_{i k}+\hat{\beta}_{1} \sum_{i=1}^{n} x_{i k} x_{i 1}+\hat{\beta}_{2} \sum_{i=1}^{n} x_{i k} x_{i 2}+\cdots+\hat{\beta}_{k} \sum_{i=1}^{n} x^{2}{ }_{i k}=\sum_{i=1}^{n} x_{i k} y_{i}
$$

These equations are much more conveniently formulated with the help of vectors and matrices.

Note: Bold-faced lower case letters will now denote vectors and matrices will be denoted by boldfaced upper case letters. In Latex, Greek letters should

$$
y=\left[\begin{array}{c}
y_{1} \\
y_{2} \\
\cdot \\
\cdot \\
\cdot \\
y_{n}
\end{array}\right], X=\left[\begin{array}{ccccc}
1 & x_{11} & x_{12} & \cdots & x_{1 k} \\
1 & x_{21} & x_{22} & \cdots & x_{2 k} \\
\cdot & \cdot & \cdot & \cdots & \cdot \\
\cdot & \cdot & \cdot & \cdots & \cdot \\
\cdot & \cdot & \cdot & \cdots & \cdot \\
1 & x_{n 1} & x_{n 2} & \ldots & x_{n k}
\end{array}\right] \beta=\left[\begin{array}{c}
\beta_{0} \\
\beta_{1} \\
\cdot \\
\cdot \\
\cdot \\
\beta_{n}
\end{array}\right], \varepsilon=\left[\begin{array}{c}
\varepsilon_{1} \\
\varepsilon_{2} \\
\cdot \\
\cdot \\
\cdot \\
\varepsilon_{n}
\end{array}\right]
$$

With this compact notation, the linear regression model can be written in the form

$$
y=X \beta+\varepsilon
$$

In linear algebra terms, the least-squares parameter estimates $\beta$ are the vectors that minimize.

$$
\sum_{i=1}^{n} \varepsilon_{i}^{2}=\varepsilon^{\prime} \varepsilon=(y-X \beta)^{\prime}(y-X \beta)
$$

Any expression of the form $\mathrm{X} \beta$ is an element of a (at most) $(k+1)$-dimensional hyperspace in $\mathrm{R}^{n}$ spanned by the $(k+1)$ columns of $X$. Imagine the columns of $X$ to be fixed, they are the data for a specific problem, and imagine $\beta$ to be variable [19-23]. We want to find the "best" $\beta$ in the sense that the sum of squared residuals is minimized. The smallest that the sum of squares could be is zero. If all ${ }_{i}$ were zero, then

$$
\hat{y}=X \hat{\beta}
$$

Here $\hat{y}^{\wedge}$ is the projection of the $n$-dimensional data vector $\mathrm{y}$ onto the hyperplane spanned by $\mathrm{X}$.

The $\hat{y}$ are the predicted values in our regression model that all lie on the regression hyperplane. Suppose further that $\hat{\beta}$ satisfies the equation above. Then the residuals $y-\hat{y}$ are orthogonal to the columns of $\mathrm{X}$ (by the Orthogonal Decomposition theorem) and thus

$$
\begin{gathered}
X(y-X \hat{\beta})=0 \\
\Leftrightarrow X^{\mid} y-X^{\mid} X \hat{\beta}=0 \\
\Leftrightarrow X^{\mid} X \hat{\beta}=X^{\mid} y
\end{gathered}
$$

These vector normal equations are the same normal equations that one could obtain from taking derivatives. To solve the normal equations (i.e., to find the parameter estimates $\hat{\beta}$ ), multiply both sides with the inverse of $X^{\mid} X$. Thus, the least-squares estimator of $\beta$ is (in vector form) [24-27].

$$
\hat{\beta}=\left(X^{\mid} X\right)^{-1} X^{\mid} y
$$

not be bold-faced. Hopefully, it should be obvious from the context whether a Greek letter signifies a random variable or a vector of random variables.

Let

Of course, this only works if the opposite exists. If the inverse does not exist, it is still possible to overcome the normal equations, but the solution will not be unique. The inverse of $X^{\prime} X$ exists, if the columns of $X$ are linearly independent [28]. That means that, as a linear combination of the other columns, no column can be written.

The vector of fitted values $\hat{y}$ in a linear regression model can be expressed as

$$
\hat{y}=X \hat{\beta}=\left(X^{\mid} X\right)^{-1} X^{\mid} y=H y
$$

The $n \times n$ matrix $H=\left(X^{\mid} X\right)^{-1} X^{\mid}$is often called the hat-matrix. It maps the vector of observed values y onto the vector of fitted values $\hat{y}$ that lie on the regression hyper-plane. The regression residuals can be written in different ways as

$$
\varepsilon=y-\hat{y}=y-X \hat{\beta}=y-H y=(I-H) y
$$

The estimate of the residual variance can still be found via the residual sum of squares $S S_{\text {Res }}$ which has the same definition as in the simple linear regression case.

$$
S S_{R e s}=\sum_{i=1}^{n} \varepsilon_{i}^{2}=\sum_{i=1}^{n}\left(y_{i}-\hat{y}_{i}\right)^{2}=\varepsilon^{\prime} \varepsilon
$$

If the multiple regression model contains $k$ predictors, then the degree of freedom of the residual sum of squares is $n-k$ (we lose one degree of freedom for the estimation of each slope and the intercept). Thus,

$$
M S_{\text {Res }}=\frac{S S_{\text {Res }}}{n-k-1}=\hat{\sigma}^{2}
$$

Model dependent is the residual variance. Its estimate changes if the model contains additional predictor variables or if predictors are omitted. It is difficult to tell which one is the "correct" residual variance. Later on, we will learn how to equate various models with each other. A smaller residual variance in a model is favored in general. 


\section{One-way ANOVA Test Procedure}

The simplest case is one-way ANOVA. A oneway analysis of variance is used when the data are divided into groups according to just one factor.

Assume that the data $x_{11}, x_{12}, x_{13}, \ldots, x_{1 n_{1}}$ are sample from population 1, $x_{21}, x_{22}, x_{23}, \ldots, x_{2 n_{2}}$ are sample from population $2, x_{k 1}, x_{k 2}, x_{k 3}, \ldots, x_{k n_{k}}$ are sample from population $k$. Let $x_{i j}$ denote the data from the $i^{\text {th }}$ group (level) and $j^{\text {th }}$ observation $[29,30]$.

We have values of independent normal random variables $\quad x_{i j}, i=1,2, \ldots ., k$ and $j=1,2, \ldots n_{i} \quad$ with mean $\mu_{i}$ and constant standard deviation $\sigma$, $x_{i j} \sim N\left(\mu_{i}, \sigma\right)$. Alternatively, each $x_{i j}=\mu_{i}+\varepsilon_{i j}$ where $\varepsilon_{i j}$ are normally distributed independent random errors, $\varepsilon_{i j} \sim N(0, \sigma)$. Let $N=n_{1}, n_{2},+\cdots+n_{k}$ is the total number of observations (the total sample size across all groups), where $n_{i}$ is sample size for the $i^{\text {th }}$ group. The parameters of this model are the population means $\mu_{1}, \mu_{2}, \ldots, \mu_{k}$ and the common standard deviation $\sigma$.

Using many separate two-sample $t$-tests to compare many pairs of means is a bad idea because we don't get a $p$-value or a confidence level for the complete set of comparisons together.

We will be interested in testing the null hypothesis

$$
H_{0}=\mu_{1}=\mu_{2}=\ldots=\mu_{k}
$$

Against the alternative hypothesis

$$
H_{0}: \exists 1 \leq i, 1 \leq k: \mu_{1} \neq \mu_{1}
$$

(There is at least one pair with unequal means).

Let $\bar{x}_{i}$ represent the mean samplei $(i=1,2, \ldots, k)$ :

$$
\bar{x}_{i}=\frac{1}{n_{i}} \sum_{j=1}^{n_{i}} x_{i j}
$$

$\bar{x}$ represent the grand mean, the mean of all the data points:

$$
\bar{x}=\frac{1}{N} \sum_{i=1}^{k} \sum_{j=1}^{n_{i}} x_{i j}
$$

$s_{i}^{2}$ represent the sample variance:

$$
s_{i}^{2}=\frac{1}{n_{i}-1} \sum_{j=1}^{n_{i}}\left(x_{i j}-\bar{x}_{i}\right)^{2}
$$

and $s^{2}=M S E$ is an estimate of the variance $\sigma^{2}$ common to all $k$ populations,

$$
s^{2}=\frac{1}{N-k} \sum_{i=1}^{k}\left(n_{i}-1\right) \cdot s_{i}^{2}
$$

ANOVA is centered on the idea to compare the variation between groups (levels) and the variation within samples by analyzing their variances.

Define the total sum of squares SST, sum of squares for error (or within groups) $S S E$, and the sum of squares for treatments (or between groups) SSC [31]:

$$
\begin{gathered}
S S T=\sum_{i=1}^{k} \sum_{j=1}^{n_{i}}\left(x_{i j}-\bar{x}\right)^{2} \\
S S E=\sum_{i=1}^{k} \sum_{j=1}^{n_{i}}\left(x_{i j}-\bar{x}_{i}\right)^{2}=\sum_{i=1}^{k}\left(n_{i}-1\right) \cdot s_{i}^{2} \\
S S C=\sum_{i=1}^{k} \sum_{j=1}^{n_{i}}\left(x_{i}-\bar{x}\right)^{2}=\sum_{i=1}^{k} n_{i}\left(x_{i}-\bar{x}\right)^{2} .
\end{gathered}
$$

Consider the deviation from an observation to the grand mean written in the following way:

$$
x_{i j}-\bar{x}=\left(x_{i j}-\bar{x}_{i}\right)+\left(x_{i}-\bar{x}\right)
$$

Notice that the left side is at the heart of SST, and the right side has the analogous pieces of $S S E$ and $S S C$. It actually works out that:

$$
S S T=S S E+S S C
$$

The total mean sum of squares $M S T$, the mean sums of squares for error $M S E$, and the mean sums of squares for treatment $M S C$ are:

$$
\begin{aligned}
& M S T=\frac{S S T}{d f(S S T)}=\frac{S S T}{N-1} \\
& M S E=\frac{S S E}{d f(S S E)}=\frac{S S E}{N-k} \\
& M S C=\frac{S S E}{d f(S S C)}=\frac{S S E}{k-1}
\end{aligned}
$$

The one-way ANOVA, assuming the test conditions are satisfied, uses the following test statistic:

$$
F=\frac{M S E}{M S E}
$$

Under $H_{0}$ this statistic has Fisher's distribution $F(k-1, N-k)$. In case it holds for the test criteria

$$
F>F_{1-\alpha, k-1, N-k} \text {, }
$$

Where $F_{1-\alpha, k-1, N-k}$, is $(1-\alpha)$-quantile of $F$ distribution with $k-1$ and $N-k$ degrees of freedom, then hypothesis

$H_{0}$ is rejected on significance level $\alpha$. The results of the computations that lead to the $F$-statistic are presented in an ANOVA table, the form of which is shown in the Table-1. 
Ibeakuzie Precious Onyedikachi \& Guobadia Emwinloghosa Kenneth., Sch Bull, Mar, 2021; 7(3): 60-71

Table-1: Basic one-way ANOVA table

\begin{tabular}{|l|l|l|l|l|l|}
\hline Variance source & $\begin{array}{l}\text { Sum of squares } \\
\text { SS }\end{array}$ & $\begin{array}{l}\text { Degrees of } \\
\text { freedom } \boldsymbol{d} f\end{array}$ & $\begin{array}{l}\text { Mean square } \\
\boldsymbol{M S}\end{array}$ & $\boldsymbol{F}$-statistic & Tail area above $\boldsymbol{F}$ \\
\hline Between & $S S C$ & $k-1$ & $M S C$ & $M S C / M S E$ & $p$-value \\
\hline Within & $S S E$ & $N-k$ & $M S E$ & - & - \\
\hline Total & $S S T$ & $N-1$ & - & - & - \\
\hline
\end{tabular}

In statistical software, p-value is used in this column of the table. If the null hypothesis holds, this $\mathrm{p}$ value shows the likelihood of rejection of the null hypothesis. In case $p<\alpha$, where $\alpha$ is chosen significance level, is the null hypothesis rejected with probability greater than $(1-\alpha) \cdot 100 \%$ probability.

\section{Analysis of covariance (ANCOVA)}

ANCOVA is a general linear model which blends ANOVA and regression. ANCOVA evaluates whether the means of a dependent variable (DV) are equal across levels of a categorical independent variable (IV) often called a treatment, while statistically controlling for the effects of other continuous variables that are not of primary interest, known as covariates $(\mathrm{CV})$ or nuisance variables $[32,33]$.

$$
y_{i j}=\mu+\tau_{i}+b\left(x_{i j}-\bar{x}\right)+\epsilon_{i j}
$$

In this equation, the $\mathrm{DV}, y_{i j}$ is the $\mathrm{jth}$ observation under the ith categorical group; the $\mathrm{CV}, x_{i j}$ is the $j$ th observation of the covariate under the $i$ th group.

Variables in the model that are derived from the observed data are $\mu$ (the grand mean) and $\bar{x}$ (the global mean for covariate $\mathrm{x}$ ). The variables to be fitted are $\tau_{i}$ (the effect of the $i$ th level of the IV), B (the slope of the line) and $\epsilon_{i j}$ (the associated unobserved error term for the $j$ th observation in the $i$ th group).

\section{DATA ANALYSIS}

Table-2: Respondent's Demographics $(\mathbf{n}=120)$

\begin{tabular}{|c|c|c|c|}
\hline S/n & Variable & & Frequency (\%) \\
\hline \multirow[t]{2}{*}{1} & \multirow[t]{2}{*}{ Gender } & Male & $62(51.7 \%)$ \\
\hline & & Female & $58(48.3 \%)$ \\
\hline \multirow[t]{5}{*}{2} & \multirow[t]{5}{*}{ Age (years) } & $23-25$ & $23(19.2 \%)$ \\
\hline & & $26-28$ & $53(44.2 \%)$ \\
\hline & & $29-31$ & $22(18.3 \%)$ \\
\hline & & $32-34$ & $2(1.7 \%)$ \\
\hline & & $35 \&$ above & $20(16.7 \%)$ \\
\hline \multirow[t]{4}{*}{3} & \multirow[t]{4}{*}{ Academic qualification } & Bachelors & $9(7.5 \%)$ \\
\hline & & PGD & $8(6.7 \%)$ \\
\hline & & MSc & $97(80.8 \%)$ \\
\hline & & $\mathrm{PhD}$ & $6(5.0 \%)$ \\
\hline \multirow[t]{8}{*}{4} & \multirow[t]{8}{*}{ Faculty } & Agriculture & $4(3.3 \%)$ \\
\hline & & Arts & $4(3.3 \%)$ \\
\hline & & Education & $15(12.5 \%)$ \\
\hline & & Engineering & $15(12.5 \%)$ \\
\hline & & Medicine & $18(15.0 \%)$ \\
\hline & & Pharmacy & $4(3.3 \%)$ \\
\hline & & Sciences & $43(35.8 \%)$ \\
\hline & & Social Sciences & $17(14.2 \%)$ \\
\hline \multirow[t]{5}{*}{5} & \multirow[t]{5}{*}{ Research types } & Qualitative socio-behavioural survey & $28(23.3 \%)$ \\
\hline & & Quantitative socio-behavioural survey & $11(9.2 \%)$ \\
\hline & & Quasi-experiment & $53(44.2 \%)$ \\
\hline & & Laboratory experiment & $17(14.2 \%)$ \\
\hline & & Clinical experiment & $16(13.3 \%)$ \\
\hline \multirow[t]{4}{*}{6} & \multirow[t]{4}{*}{ Research experience } & None & $12(10.0 \%)$ \\
\hline & & $1-2$ years & $72(60.0 \%)$ \\
\hline & & $3-4$ years & $29(24.2 \%)$ \\
\hline & & 5 years \& above & $7(5.8 \%)$ \\
\hline \multirow[t]{2}{*}{7} & \multirow[t]{2}{*}{ Any research ethics training? } & Yes & $47(39.2 \%)$ \\
\hline & & No & $73(60.8 \%)$ \\
\hline
\end{tabular}


Ibeakuzie Precious Onyedikachi \& Guobadia Emwinloghosa Kenneth., Sch Bull, Mar, 2021; 7(3): 60-71

Table-2 indicates that the study included 120 respondents, with 62 (51.7 percent) male and 58 (48.3 percent) female. The bulk (44.2 percent) of these participants is between the ages of 26 and 28. Most (80.8 percent) respondents, with few Bachelors, PGD and $\mathrm{PhD}$ degree holders, have $\mathrm{MSc}$ as their academic qualification. Examination of the demographics of respondents also reveals that different academic fields are represented in this sample, ranging from sciences (35.8 percent), medicine (15.0 percent), social sciences (14.2 percent), engineering (12.5 percent), education (12.5 percent), arts (3.3 percent), agriculture (3.3 percent), and pharmacy (12.5 percent) (3.3 percent). The majority (44.2\%) typically participate in quasiexperimental research, with the remaining few still performing qualitative socio-behavioral surveys $(23.3 \%)$, laboratory experiments $(14.2 \%)$, clinical experiments $(13.3 \%)$ and quantitative socio-behavioral surveys (13.3\%). (9.2 percent). Although several $(60.0 \%)$ participants have $1-2$ years of research experience; few $(24.2 \%)$ have 3-4 years of research experience; fewer still $(5.8 \%)$ have 5 years of research experience; the remaining few $(10.0 \%)$ participants have no research experience at all. Although few respondents (39.2 percent) stated that they have earned formal training in research ethics at different levels, many others (60.8 percent) do not have such training.

Table-3: Descriptive Statistics of test scores

\begin{tabular}{|l|l|l|}
\hline & pre_test & post_test \\
\hline $\mathrm{N}$ & 120 & 120 \\
\hline Mean & 10.05 & 16.77 \\
\hline Median & 10.00 & 17.00 \\
\hline Mode & 8 & 17 \\
\hline Std. Deviation & 3.151 & 3.358 \\
\hline Skewness & .020 & .530 \\
\hline Std. Error of Skewness & .221 & .221 \\
\hline Minimum & 4 & 12 \\
\hline Maximum & 16 & 24 \\
\hline
\end{tabular}

Results in Table-3 show that after the ethics training, the respondents performed better in the posttest $(\mathrm{x}=16.8)$ than in their pre-test $(\mathrm{x}=10.1)$. There is wide variability in respondents' scores in both tests. The frequency distribution of respondents' pre-test scores and post test scores are shown in Tables 4 and 5 .

Table-4: Frequency distribution of pre-test scores

\begin{tabular}{|l|l|l|}
\hline Score & Frequency & Percentage (\%) \\
\hline 4 & 5 & 4.2 \\
\hline 5 & 4 & 3.3 \\
\hline 6 & 9 & 7.5 \\
\hline 7 & 4 & 3.3 \\
\hline 8 & 23 & 19.2 \\
\hline 9 & 14 & 11.7 \\
\hline 10 & 4 & 3.3 \\
\hline 11 & 14 & 11.7 \\
\hline 12 & 14 & 11.7 \\
\hline 13 & 9 & 7.5 \\
\hline 14 & 10 & 8.3 \\
\hline 15 & 5 & 4.2 \\
\hline 16 & 5 & 4.2 \\
\hline Total & 120 & 100.0 \\
\hline
\end{tabular}

Table-5: Frequency distribution of post-test scores

\begin{tabular}{|l|l|l|}
\hline Score & Frequency & Percentage $(\mathbf{\%})$ \\
\hline 12 & 15 & 12.5 \\
\hline 13 & 5 & 4.2 \\
\hline 14 & 16 & 13.3 \\
\hline 15 & 10 & 8.3 \\
\hline 16 & 9 & 7.5 \\
\hline 17 & 19 & 15.8 \\
\hline 18 & 18 & 15.0 \\
\hline 19 & 9 & 7.5 \\
\hline 21 & 5 & 4.2 \\
\hline 22 & 5 & 4.2 \\
\hline 24 & 9 & 7.5 \\
\hline Total & $\mathbf{1 2 0}$ & $\mathbf{1 0 0 . 0}$ \\
\hline
\end{tabular}

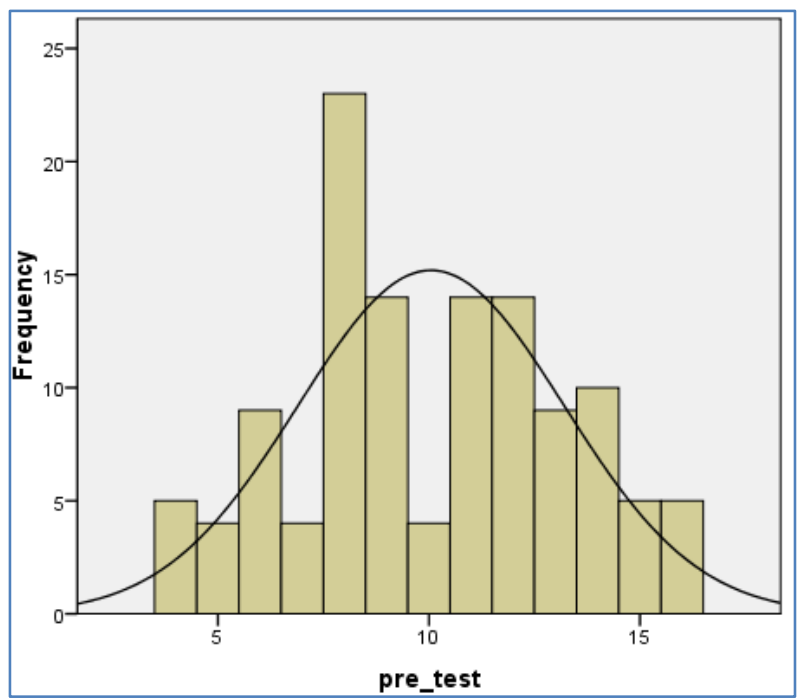

Fig-1: Graphical display of respondents' pre-test scores 
Figure-1 reveals that the ratings of respondents are favorably biased in the pre-test, as many of them performed negatively in the ethics test. This suggests that many of them have insufficient knowledge of study ethics and practice.

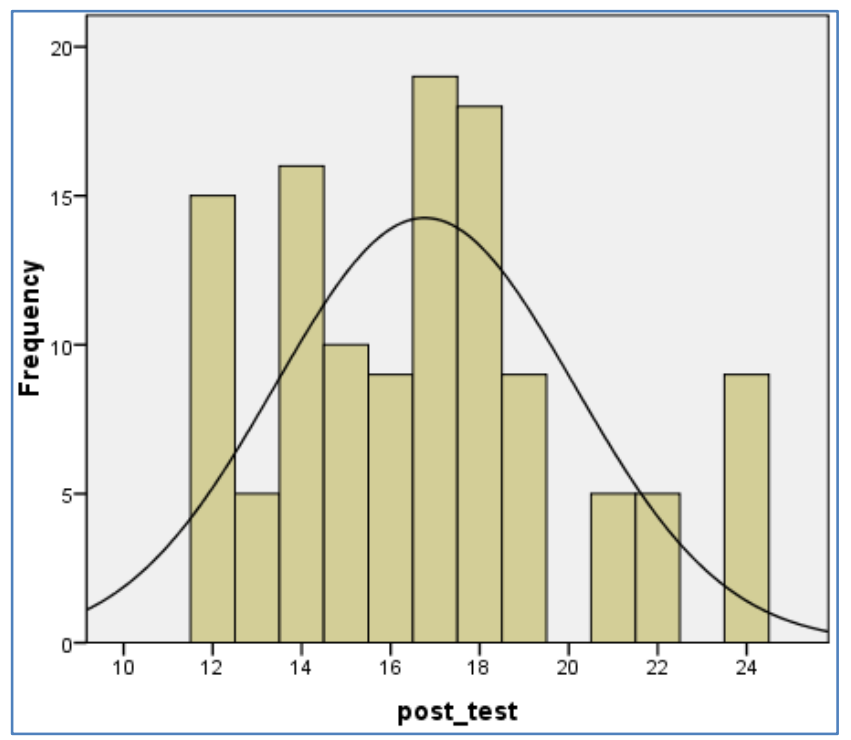

Fig-2: Graphical display of respondents' post-test scores

While the general performance of the respondents in the post-test improved, Figure 2 shows that the distribution of post-test scores by respondents is also positively biased. This suggests that during the ethics test, many of them performed below average.
This suggests that many of the respondents still have low study ethics awareness and practice, despite the small improvement in their knowledge of ethics because of the training they got.

Table-6: Relative ethics knowledge and practice of respondents in various faculties

\begin{tabular}{|l|l|l|l|l|l|}
\hline \multirow{2}{*}{ S/n } & Faculty/ Field of study & \multicolumn{2}{|l|}{ Research ethics knowledge and practice } & \multirow{2}{*}{ Pre-test } & \multirow{2}{*}{ Post-test } \\
\cline { 3 - 4 } & & Score level & Relative position & & \\
\hline 1 & Agriculture & 151 & 8 th & 9 & 14 \\
\hline 2 & Arts & 167 & 7 th & 11 & 19 \\
\hline 3 & Education & 183 & $4^{\text {th }}$ & 9 & 17 \\
\hline 4 & Engineering & 181 & $5^{\text {th }}$ & 10 & 16 \\
\hline 5 & Medicine & 189 & $3^{\text {rd }}$ & 12 & 16 \\
\hline 6 & Pharmacy & 218 & $1^{\text {st }}$ & 9 & 16 \\
\hline 7 & Sciences & 175 & $6^{\text {th }}$ & 10 & 17 \\
\hline 8 & Social Sciences & 192 & $2^{\text {nd }}$ & 11 & 19 \\
\hline Average & $\mathbf{1 8 2}$ & & $\mathbf{1 0}$ & $\mathbf{1 7}$ \\
\hline
\end{tabular}

The relative level of knowledge and practice in research ethics as well as the performance of participants in different departments are shown in Table 6. The findings indicate that, accompanied by social sciences and medicine, the Defective of Pharmacy reportedly has the highest degree of research ethics awareness and practice. On the other hand, the Faculty of Agriculture participants showed the least expertise and experience of research ethics. Overall, findings show that the perception and application of research ethics of participants continues to increase by 70 percent (from average score of 10 in pre-test to average score of 17 in post-test). This means that formal research ethics training will greatly improve the awareness and application of sound ethical standards in research efforts. 


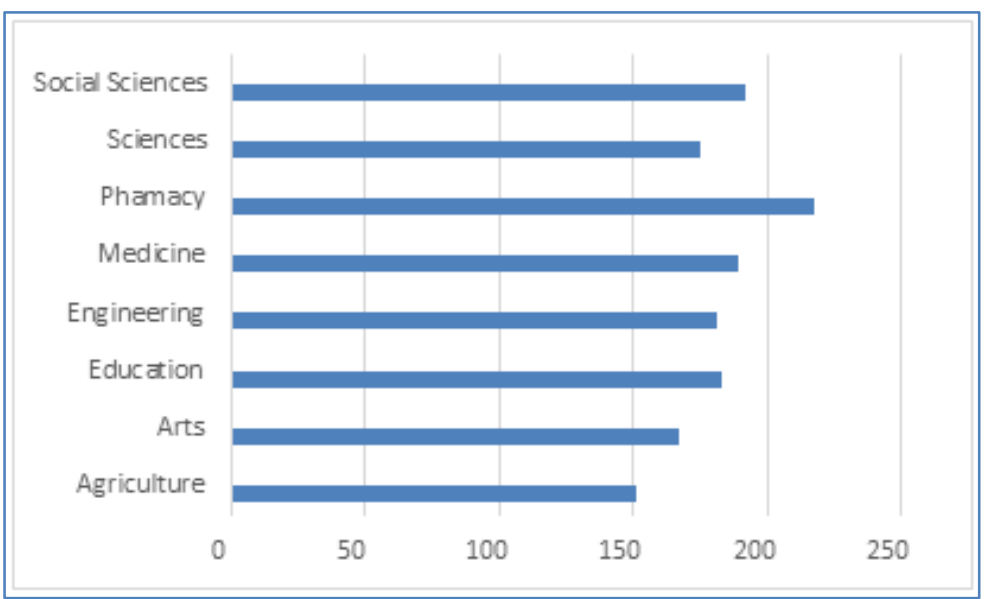

Fig-3: Graphical display of relative ethics knowledge and practice across faculties

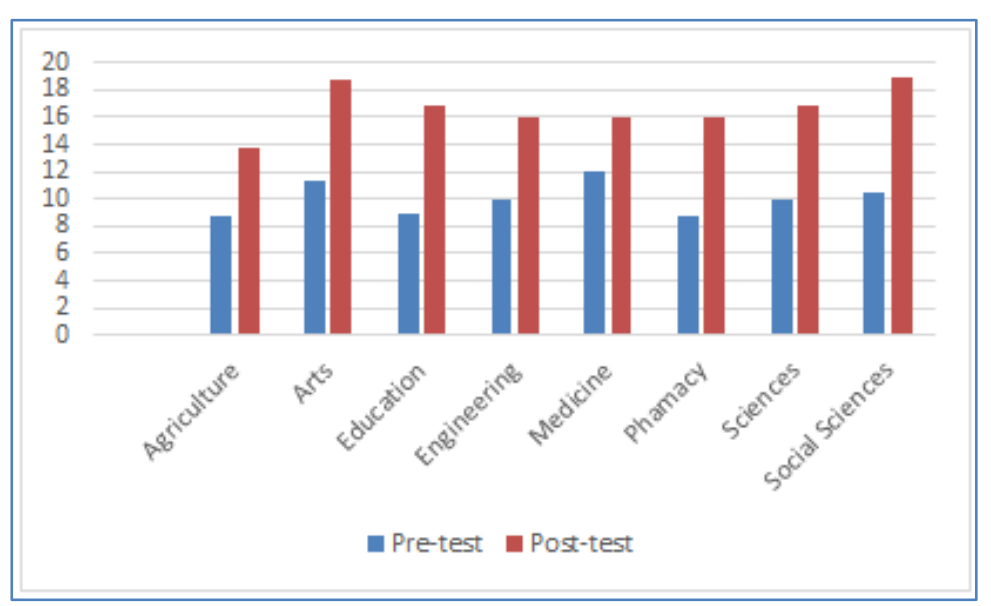

Fig-4: Graphical display of participants' pre-test and post-test scores across faculties

Table-7: Paired samples t-test

\begin{tabular}{|l|l|l|l|l|l|l|}
\hline & Mean & Std. Deviation & Std. Error & t & df & Sig. (2-tailed) \\
\hline Pre_test & 10.05 & 3.151 & .288 & 17.276 & 119 & 0.000 \\
\hline Post_test & 16.77 & 3.358 & .306 & & & \\
\hline
\end{tabular}

Results displayed in Table 4.6 reveal that participants' performance in the post-test $(x=16.77$, $\mathrm{SD}=3.36)$ is better than their average performance in the pre-test $(\mathrm{x}=10.05, \mathrm{SD}=3.15)$, and the observed difference of 6.72 in their performance is statistically significant, $\mathrm{t}(119)=17.28, \mathrm{p}<0.05$. This suggests that the ethics training that the participants received after taking the pre-test has meaningfully enhanced their knowledge of research ethics.

Table-8: Intercorrelational matrix

\begin{tabular}{|c|c|c|c|c|c|c|c|c|c|}
\hline & & Gender & Age & $\begin{array}{l}\text { Academic } \\
\text { qual. }\end{array}$ & $\begin{array}{l}\text { Research } \\
\text { types }\end{array}$ & $\begin{array}{l}\text { Research } \\
\text { expr. }\end{array}$ & $\begin{array}{l}\text { Formal } \\
\text { ethics } \\
\text { training }\end{array}$ & $\begin{array}{l}\text { Knowledge } \\
\text { base }\end{array}$ & $\begin{array}{l}\text { Ethics } \\
\text { practice }\end{array}$ \\
\hline \multirow[t]{3}{*}{ Gender } & $\begin{array}{l}\text { Pearson } \\
\text { Correlation }\end{array}$ & 1 & $-.247^{*}$ & -.007 & .103 & -.079 & -.045 & -.040 & .057 \\
\hline & Sig. (2-tailed) & & .010 & .942 & .270 & .397 & .629 & .668 & .535 \\
\hline & $\mathrm{N}$ & & 107 & 119 & 117 & 116 & 118 & 119 & 119 \\
\hline \multirow[t]{3}{*}{ Age } & $\begin{array}{l}\text { Pearson } \\
\text { Correlation }\end{array}$ & & 1 & .188 & -.117 & $.251^{*}$ & $-.256^{*}$ & -.003 & -.016 \\
\hline & Sig. (2-tailed) & & & .052 & .232 & .009 & .008 & .971 & .872 \\
\hline & $\mathrm{N}$ & & & 108 & 106 & 107 & 107 & 108 & 108 \\
\hline \multirow[t]{3}{*}{$\begin{array}{l}\text { Academic } \\
\text { qualification }\end{array}$} & $\begin{array}{l}\text { Pearson } \\
\text { Correlation } \\
\end{array}$ & & & 1 & .052 & $.230^{*}$ & .058 & .060 & $.255^{*}$ \\
\hline & Sig. (2-tailed) & & & & .572 & .013 & .533 & .518 & .005 \\
\hline & $\mathrm{N}$ & & & & 118 & 117 & 119 & 120 & 120 \\
\hline
\end{tabular}


Ibeakuzie Precious Onyedikachi \& Guobadia Emwinloghosa Kenneth., Sch Bull, Mar, 2021; 7(3): 60-71

\begin{tabular}{|c|c|c|c|c|c|c|c|c|c|}
\hline & & Gender & Age & $\begin{array}{l}\text { Academic } \\
\text { qual. }\end{array}$ & $\begin{array}{l}\text { Research } \\
\text { types }\end{array}$ & $\begin{array}{l}\text { Research } \\
\text { expr. }\end{array}$ & $\begin{array}{l}\text { Formal } \\
\text { ethics } \\
\text { training }\end{array}$ & $\begin{array}{l}\text { Knowledge } \\
\text { base }\end{array}$ & $\begin{array}{l}\text { Ethics } \\
\text { practice }\end{array}$ \\
\hline \multirow[t]{3}{*}{$\begin{array}{l}\text { Research } \\
\text { Types }\end{array}$} & $\begin{array}{l}\text { Pearson } \\
\text { Correlation }\end{array}$ & & & & 1 & -.011 & -.167 & -.010 & .088 \\
\hline & Sig. (2-tailed) & & & & & .906 & .072 & .912 & .346 \\
\hline & $\mathrm{N}$ & & & & 118 & 115 & 117 & 118 & 118 \\
\hline \multirow[t]{3}{*}{$\begin{array}{l}\text { Research } \\
\text { experience }\end{array}$} & $\begin{array}{l}\text { Pearson } \\
\text { Correlation }\end{array}$ & & & & & 1 & $-.294^{*}$ & $.189^{*}$ & .045 \\
\hline & Sig. (2-tailed) & & & & & & .001 & .041 & .632 \\
\hline & $\mathrm{N}$ & & & & & & 117 & 117 & 117 \\
\hline \multirow[t]{3}{*}{$\begin{array}{l}\text { Formal ethics } \\
\text { training }\end{array}$} & $\begin{array}{l}\text { Pearson } \\
\text { Correlation } \\
\end{array}$ & & & & & & 1 & -.070 & -.040 \\
\hline & Sig. (2-tailed) & & & & & & & .448 & .668 \\
\hline & $\mathrm{N}$ & & & & & & & 119 & 119 \\
\hline \multirow[t]{3}{*}{$\begin{array}{l}\text { Knowledge } \\
\text { base }\end{array}$} & $\begin{array}{l}\text { Pearson } \\
\text { Correlation } \\
\end{array}$ & & & & & & & 1 & .016 \\
\hline & Sig. (2-tailed) & & & & & & & & .864 \\
\hline & $\mathrm{N}$ & & & & & & & & 120 \\
\hline \multirow[t]{3}{*}{$\begin{array}{l}\text { Ethics } \\
\text { practice }\end{array}$} & $\begin{array}{l}\text { Pearson } \\
\text { Correlation }\end{array}$ & & & & & & & & 1 \\
\hline & Sig. (2-tailed) & & & & & & & & \\
\hline & $\mathrm{N}$ & & & & & & & & \\
\hline
\end{tabular}

The findings in Table- 8 show that a substantial positive relationship exists between the academic qualification of the applicant and the practice of ethics $(\mathrm{r}=0.26 ; \mathrm{p}<0.05)$. This means that the higher the academic qualification of respondents, the greater their observation of ethical values in science, or their practice. There is also a statistically important and positive connection between the research experience of the participants and their knowledge of ethics $(r=0.19$; $\mathrm{p}<0.05)$. This indicates that researchers appear to have better knowledge of research ethics as they gain more years of experience in research.

Table-9: Model Summary

\begin{tabular}{|l|l|l|l|l|}
\hline Model & $\mathbf{R}$ & $\mathbf{R}^{2}$ & Adj. $\mathbf{R}^{\mathbf{2}}$ & Std. Error \\
\hline & .326 & .106 & .051 & 32.928 \\
\hline
\end{tabular}

Predictors: (Constant), formal ethics training, gender, academic qualification, research type, research experience, age

Table-10: ANOVA

\begin{tabular}{|l|l|l|l|l|l|}
\hline Model & Sum of Squares & Df & Mean Square & F & Sig. \\
\hline Regression & 12485.103 & 6 & 2080.851 & 1.919 & .085 \\
\hline Residual & 105174.733 & 97 & 1084.276 & & \\
\hline Total & 117659.837 & 103 & & & \\
\hline
\end{tabular}

Dependent Variable: research ethics knowledge and practice

Table-11: Regression coefficients

\begin{tabular}{|l|l|l|l|l|l|}
\hline \multirow{2}{*}{ Model } & \multicolumn{2}{|l|}{ Unstandardized Coefficients } & Standardized Coefficients & \multirow{2}{*}{ Sig. } \\
\cline { 2 - 4 } & B & Std. Error & Beta & & \\
\hline (Constant) & 137.151 & 34.318 & & 3.996 & .000 \\
\hline Gender & 2.952 & 6.694 & .044 & .441 & .660 \\
\hline Age & -.545 & .786 & -.074 & -.694 & .490 \\
\hline Academic qualification & 17.095 & 5.453 & .321 & 3.135 & .002 \\
\hline Research type & 4.643 & 7.446 & .062 & .624 & .534 \\
\hline Research experience & -2.890 & 5.242 & -.058 & -.551 & .583 \\
\hline Formal ethics training & -2.924 & 7.238 & -.043 & -.404 & .687 \\
\hline
\end{tabular}

Results in Table 9 and 10 indicate that there is a linear relationship between training in formal ethics, gender, academic credentials, type of study, research experience, expertise and practice in age and research ethics. All six predictors together account for 10.6 percent of the variance found in the measurements of information and practice of ethics $[\mathrm{R}=0.326, \mathrm{R} 2=$ 0.106, Adj. For R2 = 0.051]. This model, however, does not significantly predict knowledge and practice in research ethics, $[\mathrm{F}(6,103)=1.919, \mathrm{p}>0.05]$. This 
Ibeakuzie Precious Onyedikachi \& Guobadia Emwinloghosa Kenneth., Sch Bull, Mar, 2021; 7(3): 60-71

implies that the predictor variables have no meaningful joint contribution to the criterion variable. Additional findings in Table 11 indicate that only academic credentials $\left[\beta=0.321, \mathrm{t}_{(103)}=3.135, \mathrm{p}<0.05\right]$ contributed significantly to this prediction model. This means that only the academic qualification of the sample enables the criterion variable to be predicted accurately (research ethics knowledge and practice).

Table-12: Chi-Square Tests

\begin{tabular}{|l|l|l|l|}
\hline & Value & df & Asymp. Sig. (2-sided) \\
\hline Pearson Chi-Square & 840.000 & 49 & .000 \\
\hline Likelihood Ratio & 429.398 & 49 & .000 \\
\hline N of Valid Cases & 120 & & \\
\hline $\begin{array}{l}\text { 55 cells (85.9\%) have expected count less than 5. The minimum } \\
\text { expected count is .13. }\end{array}$ \\
\hline
\end{tabular}

The findings shown in Table-7 have already shown that there are variations in levels of awareness in ethics across different departments. As shown in Table-
12, further test results suggest that these observed variations are statistically significant. The null hypothesis is, thus, denied.

Table-13: Tests of Between-Subjects Effects

\begin{tabular}{|l|l|l|l|l|l|l|}
\hline Source & $\begin{array}{l}\text { Type III } \\
\text { Sum of Squares }\end{array}$ & df & Mean Square & F & Sig. & Partial Eta Squared \\
\hline Corrected Model & 6262.045 & 3 & 2087.348 & 2.026 & .114 & .050 \\
\hline Intercept & 337128.716 & 1 & 337128.716 & 327.294 & .000 & .738 \\
\hline Pre-test & 294.828 & 1 & 294.828 & .286 & .594 & .002 \\
\hline Post-test & 6230.768 & 2 & 3115.384 & 3.024 & .052 & .050 \\
\hline Error & 119485.746 & 116 & 1030.050 & & & \\
\hline Total & 4033573.000 & 120 & & & & \\
\hline Corrected Total & 125747.792 & 119 & & & & \\
\hline$\left[\mathrm{R}^{2}=.050 ;\right.$ Adj. $\left.\mathrm{R}^{2}=.025\right]$ & & & & \\
\hline
\end{tabular}

A covariance analysis (ANCOVA) was performed in Table-13 to assess the impact of ethics training on ethical knowledge and practice of respondents, with pre-test scores acting as covariates. Post-test ethics training scores of $F(2,119)=3.02$ and a partial eta square weight of 0.05 . This effect size is not, however, statistically significant, so the null hypothesis is not dismissed.

\section{SUMMARY}

The study revealed that many respondents do not have formal training in research ethics through different faculties, although they reportedly have a few years of research experience. Study results found that respondents performed better $(\overline{\mathrm{x}}=16.77, \mathrm{SD}=3.36)$ after being subjected to ethics training, while the generality of these respondents showed weak research ethics awareness and practice $(\bar{x}=10.05, S D=3.15)$. In their results, the observed difference of 6.72 is statistically important, $\mathrm{t}(119)=17.28, \mathrm{p}<0.05$. This suggests that training in research ethics has the potential to have a positive effect on the understanding and practice of ethics of students in their research activities, as formal training in research ethics would greatly strengthen sound ethical principles and practices. More successful and systematic research ethics training would help to boost the understanding of students and the applicability of ethical concepts to research. While there were differences in ratings, the study results also pointed out that there are deficits in research ethics skills across the different faculties. This underpins the interdisciplinary character, applicability and weight of the understanding and practice of research ethics in the university system. Results showed that there is a statistically important and positive association between the academic qualification of students and the knowledge/practice of ethics $(r=0.26 ; p<0.05)$, suggesting that higher academic qualifications appear to be directly linked to the practice of study ethical principles. Similarly, there is a statistically significant and direct relationship between students' research experience and their ethics knowledge $(r=0.19 ; \mathrm{p}<$ $0.05)$, which means that when students engage in research activities for more years, they will tend to have more exposure and better knowledge of research ethics. The regression model revealed a linear relationship between formal ethics training, gender, academic qualification, research type, research experience, and age and research ethics knowledge/practice. The predictors jointly account for some observed variance in the measures of ethics knowledge and practice $[\mathrm{R}=$ $0.326, \mathrm{R}^{2}=0.106$, Adj. $\left.\mathrm{R}^{2}=0.051\right]$. However, the model does not reliably predict research ethics knowledge and practice $\left[\mathrm{F}_{(6,103)}=1.919, \mathrm{p}>0.05\right]$, implying that there is no sufficient empirical evidence that these predictor variables have a combined weight that could determine the criterion variable. But in the model, students' academic qualifications $[\beta=0.321, \mathrm{t}$ $\left.{ }_{(103)}=3.135, \mathrm{p}<0.05\right]$ significantly predict the criterion 
Ibeakuzie Precious Onyedikachi \& Guobadia Emwinloghosa Kenneth., Sch Bull, Mar, 2021; 7(3): 60-71

variable (research ethics knowledge and practice). The null hypothesis that there is no substantial difference in the level of knowledge of ethics among students in different faculty/study fields is rejected. The findings of the analysis have shown that the variations found in the levels of awareness of ethics across different departments are statistically important. The second null hypothesis that there is no substantial influence or effect of ethics training among university students on ethical knowledge and practice is not rejected $[\mathrm{F}(2,119)=$ $3.02, \mathrm{p}>0.05$ ] as the ANCOVA effect size is 0.05 in the partial eta square $\left(\eta^{2}\right)$ and is not statistically significant.

\section{CONCLUSIONS}

The critical assessment in this study showed that the awareness and practices of research ethics among undergraduate students at the University of Benin are poor, although this could be dramatically improved with formal training in ethics research that will enhance sound ethical conduct of research among the population of students.

\section{REFERENCES}

1. Figueiredo, C. C., \& Silva, A. F. (2018). Application of Regression Modeling to Data Observed Over Time, Revista Eletrônica de Negócios Internacionais, Internext, São Paulo, 13(3), 42-50.

2. Ruyter, K. W., Førde, R., \& Solbakk, J. H. (2000). Medisinsk etikk. En problembasert tilnarming [Medical ethics. A problem based approach]. Oslo: Gyldendal Akademisk. 251-253.

3. Van Rensselaer Potter Potter. (1971). Van Rensselaer. Bioethics: bridge to the future. Englewood Cliffs, N.J.: Prentice-Hall.

4. Andre, J. (2002). Bioethics as practice The University of North Carolina Press.

5. Scandals and Tragedies of Research with Human Participants. In History of Research Ethics

6. Christopher, O. (2009). Agulanna. History of Research Ethics, West African Bioethics Program.

7. Adebamowo, C. A. (2005). Ethical issues in cancer research, 2005. The human radiation experiments: Final report of the president's advisory committee, Oxford UP 1996, 74-109.

8. Katz, J. (1972). Experimentation without restriction. In Experimentation with human beings.

9. Aasen, H. S. (2000). Pasientens rett til selvbestemmelse ved medisinsk behandling. Bergen: Kunnskapsforlaget

10. Ariansen, P. (1992). Miljøfilosofi. En innføring. Oslo: Universitetsforlaget.

11. Bernard, C. (1865). Introduction à l'étude de la mèdecine expèrimentale. Paris: Bailliere. Translated to English in 1927, republished in 1957 with the title An introduction to the study of experimental medicine. New York: Dover.
12. Osuji G. A., Obubu, M., Obiora-Ilouno H. O. (2016). An investigation on the causes of Low birth weight in Delta State, Nigeria. European Journal of Statistics and Probability, 4(1):1-6.

13. Osuji G. A., Obubu, M., \& Obiora-Ilouno H. O (2015). An Investigation on Crime Rate in Southeastern Nigeria. European Journal of Statistics and Probability, 3(4):1-9.

14. Carson, R. (1962). Silent spring. New York: Houghton Lifflin. Published in 2000 with a new introduction by P. Matthiessen. London: Folio Society.

15. Elkeles, B. (1996). Der moralische Diskurs über das medizinische Menschenexperiment im 19. Jahrhundert. Stuttgart: Gustav Fischer.

16. Faden, R. R., Beuchamp, T. L., \& King, N. M. P. (1986). A history and theory of informed consent. New York: Oxford University Press.

17. Ferry, G. (1998). Dorothy Hodgkin: a life. London: Granta

18. Grodin, M. A., \& Glantz, L. H. (1994). Children as research subjects. Science, ethics and law. Oxford: Oxford University Press

19. Hovedkomiteen for norsk forskning. (1981). Forskning og etisk ansvar. Oslo: Hovedkomiteene for norsk forskning.

20. Kenneth, G. E. (2021). Statistical Application of Regression techniques in Modeling Road Accidents in Edo State, Nigeria. Sch J Phys Math Stat, 1, 1418.

21. Maxwell O., Happiness, O. I., Alice, U. C., \& Chinedu, I. U. (2018). An Empirical Assessment of the impact of Nigerian All Share Index, Market Capitalization, and Number of Equities on Gross Domestic Product. Open Journal of Statistics, 8 , 584-602. https://doi.org/10.4236/ojs.2018.83038

22. Obubu, M., Oyafajo, O. A., Anyawu. I. F., Olayemi. J.I. (2019). Modeling Typhoid Mortality with Box-Jenkins Autoregressive Integrated Moving Average Models. Scholars Journal of Physics, Statistics, and Mathematics, 6(3): 29-34.

23. Kenneth, G. E. (2021). Econometric Modeling of Nigeria's GDP; A Variable Selection Approach. Sch J Econ Bus Manag, 1, 14-25.

24. Kenneth, G. E. (2021). A Statistical Outlook into the Distribution of Crimes in Nigeria Using Principal Component Analysis. Sch J Phys Math Stat, 1, 1-7.

25. Johansen, M. W., Kaspersen, K. B., \& Skullerud, A. M. B. (2001). Personopplysningsloven: kommentarutgave. Universitetsforl.

26. Kaiser, M. (2000). Hva er vitenskap? Oslo: Universitetsforlaget.

27. Patrix, J. M. (1997). Gerhard Armauer Hansen. Leprabasillens oppdager. Bergen: Eide

28. President's advisory committee. (1996). Final report: Ethics of human subjects' research: a historical perspective. Human radiation research. Oxford: Oxford University Press. 
29. Ruyter, K. W. (Ed.). (2003). Forskningsetikk: beskyttelse av enkeltpersoner og samfunn. Gyldendal akademisk.

30. Kenneth, G. E., Besiru, M., \& Kelvin, O. I. (2021). A Time Domain Approach to Modeling Nigeria's Gross Domestic Product. Sch J Phys Math Stat, 1, 19-28.

31. Ruyter, K.W., Reidun, F., \& Jan, Helge, Solbakk. (2000). Medisinsk etikk - en problembasert tilnærming. Gyldendal Norsk Forlag AS, Oslo.
32. Schultz, W. J. (1968). The humane movement in the United States, 1910-1922. New York: AMS Press.

33. Osuji, G. A., Obubu, M., \& Nwosu, C. A. (2016). Stock Investment Decision in Nigeria; A PC Approach. World Journal of Multidisciplinary and Contemporary Research, 2(1):1-11. 